\title{
Bone Marrow Study in Patients of Pancytopenia
}

\author{
*Dr.Sapna Dhakad ${ }^{1}$, Dr. Sudha Iyengar², Dr. Bharat Jain", \\ ${ }^{I}$ Resident(M.D),Department Of Pathology, \\ ${ }^{2}$ Associate Proffessor Department Of Pathology \\ ${ }^{3}$ Hod Department Of Pathology \\ Corresponding Author: * Dr.Sapna Dhakad
}

\begin{abstract}
Introduction: Pancytopenia is defined as reduction in all three major componpents of blood,results from number of disease processes. Pancytopenia develops by varieties of mechanism, due to decrease in haematopoeitic cell production as a result of destruction of marrow by toxins suppression of normal growth and differentiation. Patients present with anaemia leucopenia and thrombocytopenia

Material And Methods: This is study done retrospectively of 80 patients from january 2015 to december $2016(2$ year study), presenting with pancytopenia, in central pathology lab of Gajra Raja medical College Gwalior in which both peripheral smear and bone marrow of same patient is examined aftre staining with leishman stain under low and high magnification and all haematological parameters were seen. Bone marrow is evaluated for cellularity,erythropoiesis,myelopoiesis,megakaryopoiesis and other cells.

Results: Among 80 cases studied,age of patients ranged from 1 to 70 with male to female ratio 2:1. Maximum number of cases were found in in the age group of $1-15 \mathrm{yrs}(62.5 \%) 15-35(25 \%)$ and $>35$ yrs(12.5\%).most of the patients (>80\%) had haemoglobin less than 5 grams,.more than $60 \%$ had mcv more than 100fml.In bone marrow studies we have found that myeloid series is suppressed in more than 60\%patients and its normal in other patients.Myeloid erythroid ratio is suppressed in $70 \%$ of the cases.
\end{abstract}

\section{Introduction}

Pancytopenia is a common haematological entity leads to reduction all the three major components of blood . Criteria for diagnosis of pancytopenia are :- haemoglobin less than $10 \mathrm{gms} / \mathrm{dl}$,TLC less than 3500/cumm platelet count less than 100,000/cumm(1). In order to establish the cause of pancytopenia, Bone Marrow Aspirationis needed which can be done from Manubrium Sterni, Iliac Crests or Upper End of Tibia in case of children or Upper End of Tibia in case of children. . In today's era, aspiration of bone marrow is an indispensable adjunct to the study of diseases of the blood and in certain circumstances is the only way by which a correct diagnosis can be made of hematological and some non-hematological disorders. Bone marrow can be obtained by needle aspiration, percutaneous trephine biopsy or surgical biopsy. Bone marrow aspiration is an outdoor procedure which is simple, safe and not much time consuming. The spectrum of disorders primarily or secondarily affecting the bone marrow may manifest with peripheral pancytopenia (2). Pancytopenia develops The spectrum of disorders primarily or secondarily affecting the bone marrow may manifest with peripheral pancytopenia (2). Pancytopenia develops by varieties of mechanisms such as decrease in hematopoietic cell production as a result of destruction of marrow by toxins or suppression of normal marrow growth and differentiation.(3) Pancytopenia can be caused by various mechanisms such as reduction in haematopoetic cell production due to destruction of bone marrow by toxins or by formation of defective cells that are rapidly removed from the circulation. Common clinical manifestations are pallor,fatigue, splenomegaly, lymphadenopathy, fever, bleeding,weight loss, hepatomegaly and jaundice (4)

\section{Material And Methods}

This is a 2 years retrospective study of 80 patients from january 2015 to december 2016, presenting with pancytopenia, in central pathology lab of Gajra Raja medical College Gwalior in which both peripheral smear and bone marrow of same patient were examined after staining with leishman stain under low and high magnification and all haematological parameters were seen. Bone marrow is evaluated for cellularity,erythropoiesis,myelopoiesis,megakaryopoiesis and other cells. The cytology preparation of bone marrow cells obtained by aspiration of the marrow a smear of the cells, allowing excellent visualization of the morphology \& enumeration of the cells. (5)

III. Results

Among 80 cases studied,age of patients ranged from 1 to 70 years with male to female ratio 2:1. Maximum number of cases were found in in the age group of $1-15 y$ rs $(62.5 \%) 15-35(25 \%)$ and $>35$ 
yrs(12.5\%).most of the patients (>80\%) had haemoglobin less than 5 gram $\%$. More than $60 \%$ had MCV greater than 100fl. In bone marrow studies we have found that myeloid series is suppressed in more than $60 \%$ patients and its normal in other patients. Myeloid erythroid ratio is suppressed in $70 \%$ of the case. So most common aspiration finding was megaloblastic anaemia with pancytopenia followed by pancytopenia, erythroid hyperplasia with mild megaloblastic changes,hypoplastic marrow, normocytic normochromic with pancytopenia,few cases of mixed nutritional deficiency and aplastic anaemia were also found. We couldn't found the exact cause of pancytopenia due to problems of follow up.

Table 1. Haemoglobin

\begin{tabular}{|l|l|l|}
\hline $\mathrm{Hb}$ & $<5 \mathrm{~g} / \mathrm{dl}$ & $>5 \mathrm{~g} / \mathrm{dl}$ \\
\hline Number of pt. & 50 & 30 \\
\hline$\%$ & $62.5 \%$ & $37.5 \%$ \\
\hline
\end{tabular}

Table 2. Mean corpuscular volume

\begin{tabular}{|l|l|l|}
\hline MCV & $80-100 \mathrm{fl}$ & $>100 \mathrm{fl}$ \\
\hline No.of pt. & 28 & 52 \\
\hline$\%$ & $35 \%$ & $65 \%$ \\
\hline
\end{tabular}

Table 3 Erythroid Series-

\begin{tabular}{|l|l|l|l|l|}
\hline Bone marrow & Hyperplasia & Suppressed & Normoblastic & Megaloblastic \\
\hline No.of pt. & 25 & 18 & 25 & 12 \\
\hline$\%$ & $31.2 \%$ & $22.5 \%$ & $31.2 \%$ & 15 \\
\hline
\end{tabular}

Fig. No.1 age wise distribution

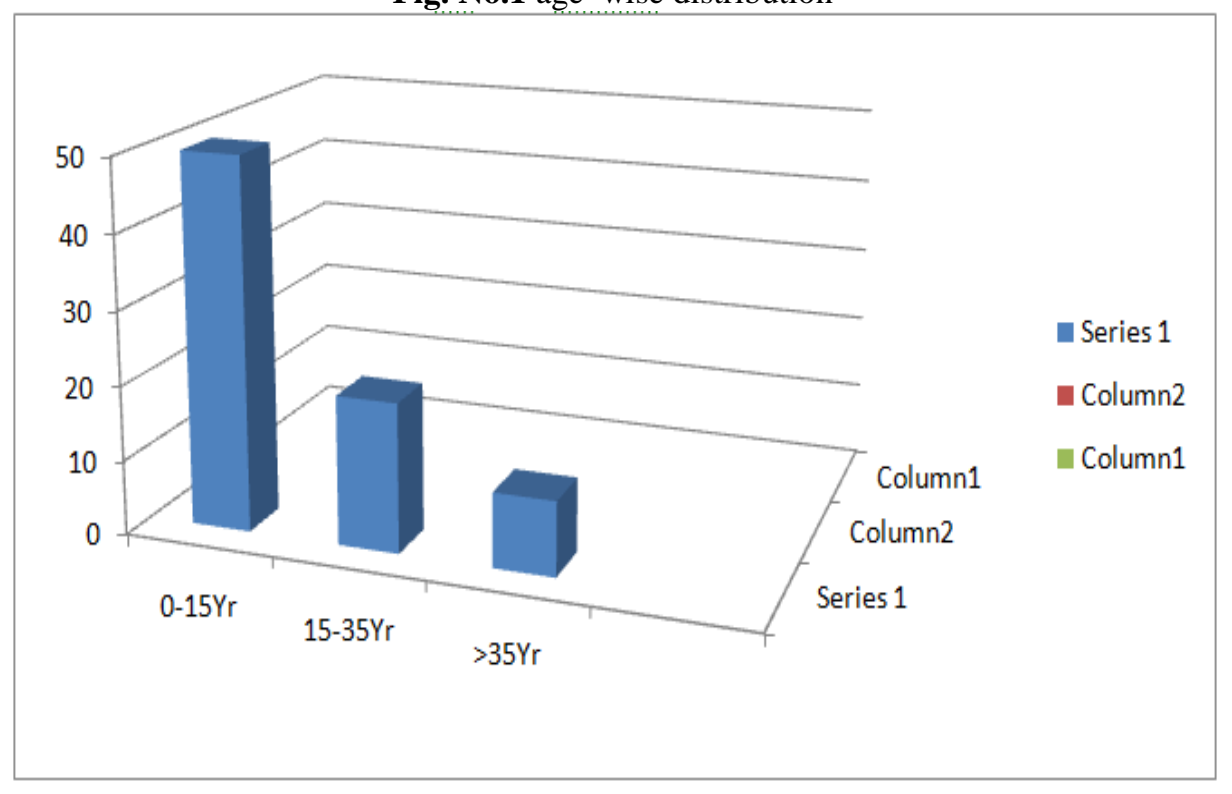

Table no. 4. Bone marrow findings

\begin{tabular}{|c|c|c|c|c|c|c|c|c|c|}
\hline & $\begin{array}{l}\text { Nomocytic } \\
\text { nomochromic } \\
\text { with } \\
\text { pancytopenia }\end{array}$ & $\begin{array}{l}\text { Microblastic } \\
\text { maturation, } \\
\text { microcytic } \\
\text { hypochromic } \\
\text { most probably } \\
\text { iron } \\
\text { deficiency } \\
\text { anemia }\end{array}$ & Pancytopenia & $\begin{array}{l}\text { Mixed } \\
\text { nutritional } \\
\text { deficiency } \\
\text { with } \\
\text { megaloblastic } \\
\text { maturation }\end{array}$ & $\begin{array}{l}\text { Megaloblastic } \\
\text { anemia with } \\
\text { pancytopenia }\end{array}$ & $\begin{array}{l}\text { Hypoplastic } \\
\text { narrow with } \\
\text { nomoblatic } \\
\text { type }\end{array}$ & $\begin{array}{l}\text { Erythroid } \\
\text { hypemlasia } \\
\text { with mild } \\
\text { megaloblastic } \\
\text { changes }\end{array}$ & $\begin{array}{l}\text { Erythroid } \\
\text { hypemlasia } \\
\text { with } \\
\text { nomoblastic } \\
\text { narrow with } \\
\text { megaloblastic } \\
\text { changes }\end{array}$ & $\begin{array}{l}\text { Aplastic } \\
\text { anemia }\end{array}$ \\
\hline No. of cases & 4 & 2 & 22 & 2 & 30 & 6 & 10 & 3 & 1 \\
\hline$\%$ & 5 & 2.5 & 3125 & 2.5 & 37.5 & 7.5 & 125 & 3.75 & 1.25 \\
\hline
\end{tabular}




\begin{tabular}{|c|c|c|c|c|c|}
\hline $\begin{array}{l}\text { Study } \\
\text { Year cause }(\%)\end{array}$ & Country & year & No. of cases & Commonest cause & $\begin{array}{l}\text { Second most } \\
\text { common cause }\end{array}$ \\
\hline Jha et al 5 & Nepal & 2007 & 148 & $\begin{array}{l}\text { Hypoplastic anemia } \\
(29.05)\end{array}$ & $\begin{array}{l}\text { Megaloblastic } \\
\text { anemia23.64) }\end{array}$ \\
\hline Makaju et al8 & Nepal & 2009 & 28 & $\begin{array}{l}\text { Megaloblastic } \\
\text { anemia(42.85) }\end{array}$ & $\begin{array}{l}\text { Aplastic anemia } \\
(35.7)\end{array}$ \\
\hline $\begin{array}{l}\text { International } \\
\text { agranulocytosis and } \\
\text { aplastic } \\
\text { anemia study group9 }\end{array}$ & Israel and Europe & 1987 & 319 & $\begin{array}{l}\text { Hypoplastic anemia } \\
(52.7)\end{array}$ & MDS (4.5) \\
\hline $\begin{array}{l}\text { Keisu and ost10 } \\
1990 \quad 100\end{array}$ & Israel and Europe & 1990 & 100 & $\begin{array}{l}\text { Neoplastic disease, } \\
\text { radiation (32) }\end{array}$ & $\begin{array}{l}\text { Hypoplastic } \\
\text { anemia (19) }\end{array}$ \\
\hline Hossain et al11 & Bangladesh & 1992 & 50 & Hypoplastic anemia & $\begin{array}{l}\text { Chronic malaria } \\
\text { and kalazar }\end{array}$ \\
\hline $\begin{array}{l}\text { Varma and Dash12 } \\
\text { India }\end{array}$ & India & 1992 & 202 & $\begin{array}{l}\text { Hypoplastic anemia } \\
(40.6)\end{array}$ & $\begin{array}{l}\text { Megaloblastic } \\
\text { anemia (23.3) }\end{array}$ \\
\hline $\begin{array}{l}\text { Present study } \\
2016 \quad 80\end{array}$ & india & 2016 & 80 & $\begin{array}{l}\text { megaloblastic } \\
\text { anaemia (37.5) }\end{array}$ & $\begin{array}{c}\text { pancytopenia } \\
\text { (nutritional) }\end{array}$ \\
\hline
\end{tabular}

\section{Discussion}

In pancytopenia the mechanism is either associated with decrease in haematopoietic cell production or suppression and differentiation in bone Marrow,but in some patient bone marrow finding shows normal cellurarity or hypercellularity or even no abnormal cells may be present. Pancytopenia is a common haematological finding with variable clinical presentation. The causes of pancytopenia can be :

a) Ineffective haematopoiesis with cell death inthe marrow.

b) Formation of defective cells which are rapidlyremoved from circulation.

c) Sequestration and/or destruction of cells by the action of antibodies or,

d) Trapping of normal cells in a hypertrophied and over-reactive reticuloendothelial system.

In this study of 80 cases of bone marrow finding, we have found that most common cause of pancytopenia is megaloblastic anaemia.This increased incidence of megaloblastic anaemia mainly Due to nutritional anaemia in our country and thease parient responded with appropriate treatment.Majority of the patients were male and at the age 14 to 20 years.In bone marrow of megaloblastic anaemia we can see megaloblast with sieve like chromatin(shown in fig 2), nucleus maturation lacks behind cytoplasmic maturation. In our study we had 10 cases of erythroid hyperplasia (figure 3) marrow is markedly hypercellular with erythroid hyperplasia. Erythroid precursor showed megaloblastosis and predominance of early and intermediate megaloblas, other causes of pancytopenia are nutritional deficiency ,hypoplastic marrow( 6 cases) in our study and aplastic anaemia( 1 case) .Bone marrow findindg in apastic anaemia shows few mast cells,plasma cells as shown in (fig 4 and 5).Total 4 cases of normocytic normochromic anaemia with pancytopenia was identified. Various factors encompassing geographic distribution and genetic disturbances may cause variation in the incidence of disorders causing pancytopenia( $6,7,8$ )

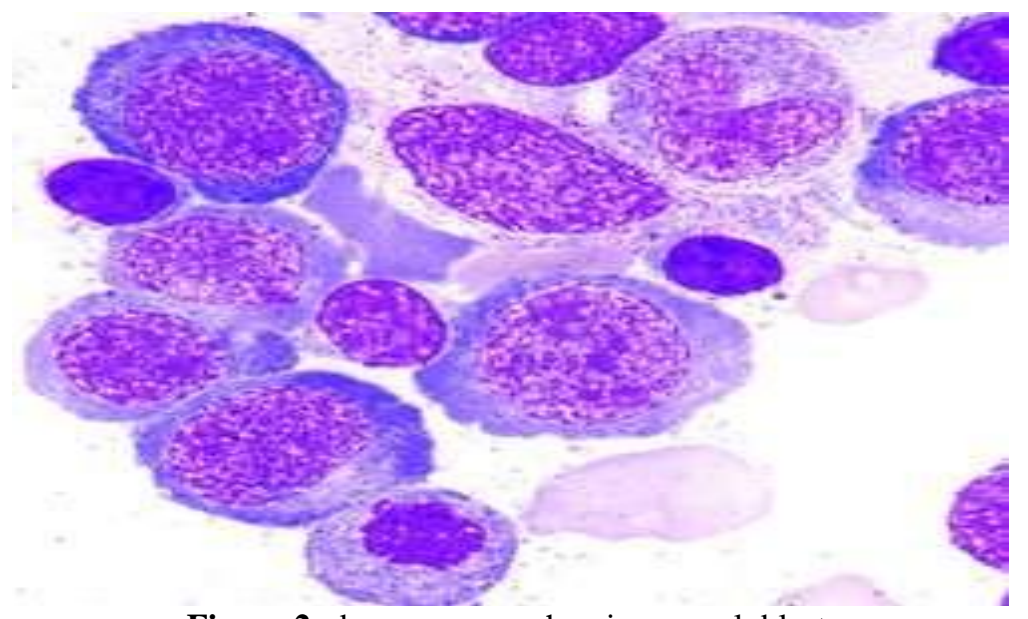

Figure 2- bone marrow showing megaloblast 


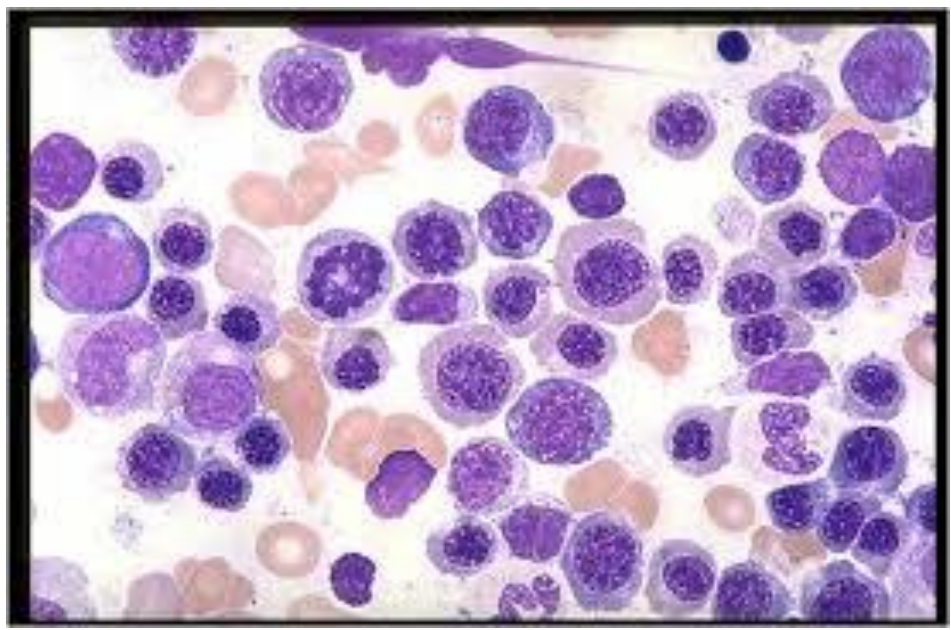

Figure 3. Bone marrow showing erythroid hyperplasia

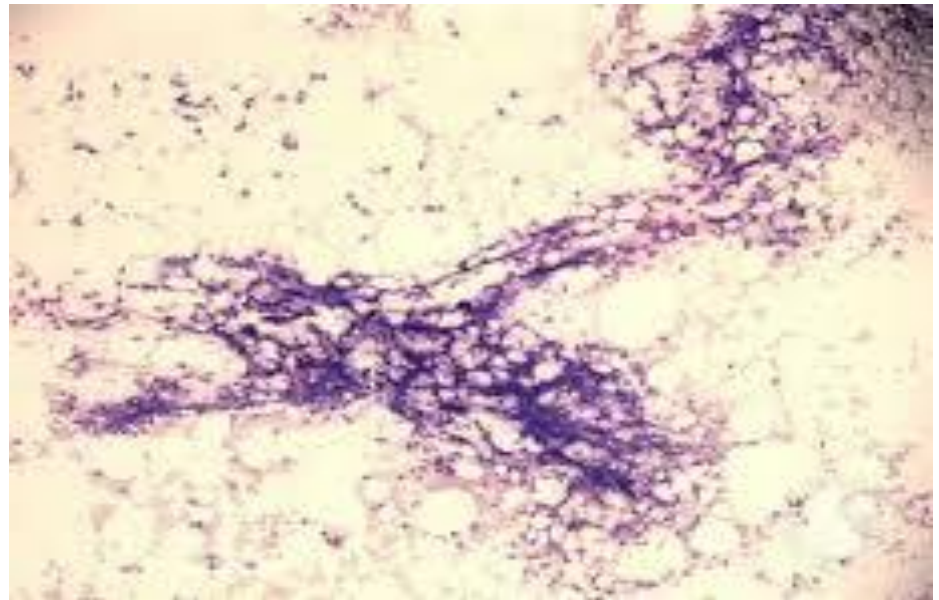

Figure 4- showing bone marrow of aplastic anaemia

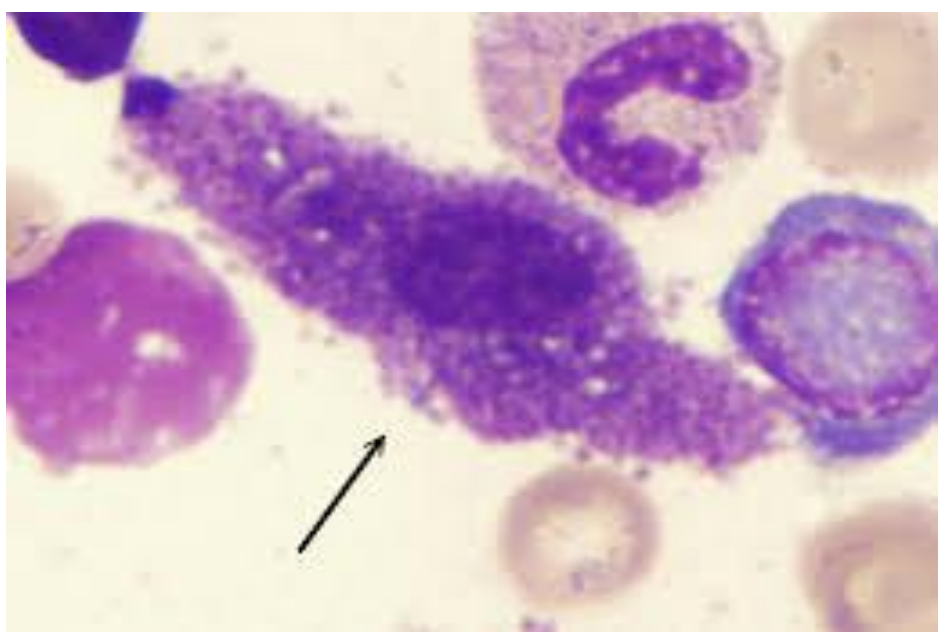

Figure 5 showing mast cell in aplastic anaemia

\section{Conclusion}

Pancytopenia is a very common haematological problem that comes in clinical practice. Physical examination, peripheral blood finding and all haematological investigation along with bone marrow aspiration play an important role for diagnosis or to rule out the cause and in planning further investigation and management of cytopenic patient. Megaloblastic anaemia, hypoplastic marrow(nutritional) are the most common cause of pancytopenia, however other causes such as infection, storage disorder and other rare disease should be taken into consideration. 


\section{Bibliography}

[1]. Tilak N, Jain R. Pancytopenia - A clinical haematological analysis of 77 cases. Indian J Pathol

[2]. Williams WJ, Bentkr E, Erskv AJ. Haematology - third edition, Singapore, McGraw Hill Book Company

[3]. Williams MD. Pancytopenia, aplastic anemia and pure red cell aplasia. In: Lee RG, Foerster J, Lukens J, Paraskevas F, Greer JP,

Rodgers GM, (eds). Wintrobe's Clinical Haematology 10th edn.

[4]. Tariq M, Khan N, Basri R, Amin S. Aetiology of pancytopenia. Guinan EC, Shimamura A. Wintrobe's Clinical Hematology. In: Greer JP, Foerster J, Lukens JN, Rodgers

[5]. GM, Paraskevas F, Glader B, editors. Acquired and inherited aplastic anemia syndromes. 11th ed. international agranulocytosis and aplastic-419 study. Incidence of aplastic anaemia, the relevance of diagnostic criteria. Blood 1987; 70: 1718-21.

[6]. Wintrobe MM (ed). Clinical Haematology. Eighth edition, Philadelphia: Lea and Febiger 1981; pp 699- 915.

[7]. Keisu M, Ost A. Diagnosis in patients with severe pancytopenia suspected of having aplastic anaemia. Eur J Haematol 1990; 45: 11-4.

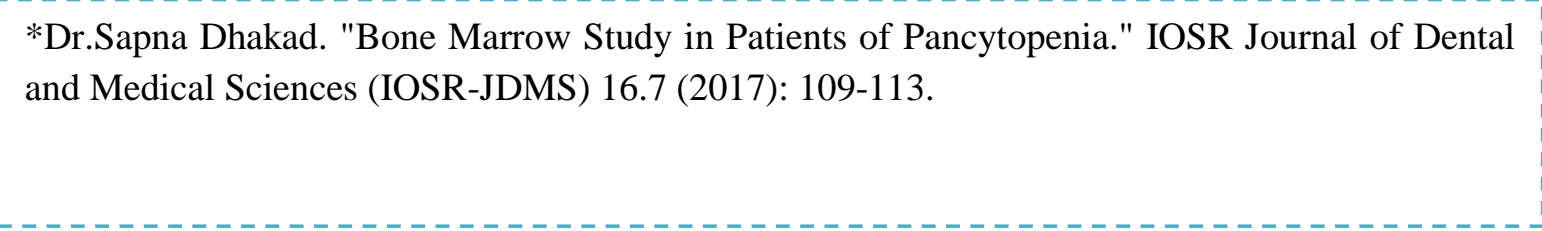

